\title{
Criminal Law Protection Of Giving Rights Of Liability Is Not The Debtor
}

\author{
Euis Listianti ${ }^{1}$ and Umar Ma'ruf ${ }^{2}$
}

\begin{abstract}
In the practice of the loan agreement with collateral Mortgage made by banks as creditors, so if the debtor defaults in performing its debt to the creditor, the creditor has the right to make the execution of security object Encumbrance with its own power after first obtaining fiat yustitsia of the chairman of the court country where the land is located. In case of dispute the auction execution of mortgage security object between the Bank as the creditor with $\mathrm{Zn}$ as the debtor, as creditors of the bank's declared to have violated provisions of the law in the execution of security object security rights belonging to the debtor $\mathrm{Zn}$. But in fact the execution and the execution of the auction object of mortgage collateral is in accordance with the provisions of Article 6 and Article 20 UUHT No. 4 of 1996 and also in accordance with the provisions and procedures of the auction procedure execution security object security rights under the laws of the auction. The problems addressed in this study is how to legality and legal power auction object execution Mortgage guarantees made at the request of creditors certificate holder.

Keywords: Legal Protection, Criminal, and Encumbrance .
\end{abstract}

\section{Introduction}

Basically every person living in the world in meeting their needs can not be done alone without other people. Everyone should have a relationship with another person to meet all his needs. There is a connection with a legal effect and there is a relationship that has no legal effect. Relationship with a legal effect with rights and obligations. This makes the rapidly growing law as well as treaty law. During its development, the existing law is not accompanied by progress in the field of legal and regulatory reform. ${ }^{3}$ Interaction of a society that is more universal (global) frequently lead to conflicts of law in theory and practice implementation. Another consequence of this interaction is the emergence of a wide variety of forms of agreements. An agreement is a legal act whereby a person promised to someone else or the two men promised each other to implement something, whereas the agreement itself is one source of the engagement other than legislation. ${ }^{4}$

The provisions of Article 1233 Book of the Civil Law states:

"Each engagement is born either for approval or agreement, either because of legislation"

Book III of the Civil Code of Commitments regulating the general provisions and special provisions. Contains general provisions of the regulations that apply to the engagement in general, the general provisions set out terms which may be applied either to the agreements stipulated in the Civil Code and outside the Civil Code, for

\footnotetext{
${ }^{1}$ Student of Master of Law, Universitas Islam Sultan Agung Semarang and Listi Law Firm, Email: elistianti19@gmail.com

${ }^{2}$ Lecturer of Faculty of Law Unissula

${ }^{3}$ Salim HS 2004 Perkembangan Hukum Jaminan di Indonesia Jakarta: PT. Radja Grafindo Persada p 25

${ }^{4}$ Ibid p. 30
} 
example, how the birth of engagement, kind of engagement and the abolishment of the engagement. Contains specific provisions on rules that are widely used in the community and who have a particular name for example: purchase, lease, civil union. Special provisions also called Named Agreement. ${ }^{5}$

Rachmadi Usman provide collateral as a means of understanding the security protection of creditors, the debtor's repayment certainty on the implementation of an accomplishment by the debtor or by a guarantor of the debtor. ${ }^{6}$ While Hasanuddin Rahman expressed understanding as dependents guarantee provided by the debtor and the creditor or a third party because the creditor has an interest that a borrower must fulfill its obligations in an engagement. ${ }^{7}$

Based on the above understanding collateral, can determine the function of guarantee is as follows:

- Gives the right and authority to the bank to obtain repayment of the results of the sale of goods such guarantees if borrowers do default.

- Ensuring that customers participate in the transaction to finance its business.

- Giving impetus to the debtor to meet his achievements to the creditor. ${ }^{8}$

By type, the guarantee can be divided into individual guarantees and collateral material. Individual guarantee (borgtoch / personal guarantee) is a guarantee in the form of statement of capability provided by a third party in order to ensure the fulfillment of the obligations of the debtor to the creditor, if the debtor is concerned breach of contract (default). ${ }^{9}$ This guarantee is basically underwriting of debt set forth in Civil Code Section 1820-1850. In its development, the individual guarantee is also practiced by companies that guarantee the debt of other companies. Bank in this case often received similar assurances, often called corporate guarantee.

While collateral material (zakelijke zekerhed / security right in rem) is a guarantee in the form of wealth by means of separation of part of the assets of both the debtor and third parties, in order to ensure the fulfillment of the obligations of the debtor in question breach of contract (default). By its very nature, this material guarantees can be divided into two, namely: a guarantee of material with tangible objects and intangible collateral material. Collateral material with tangible objects can be objects or objects moving and not moving. While collateral with intangible objects can be either accounts receivable or the right to collect. ${ }^{10}$ Article 1754 to Article 1769 of the Civil Code became the basis of the credit agreement, in which set the terms for the agreement of the lending and borrowing of money or goods that are depleted due to the use and required that the debtor or the debtor will repay the loan with the lender in an amount equal of sorts and the same circumstances as well. Furthermore, also

\footnotetext{
${ }^{5}$ Ibid., p. 40

${ }^{6}$ Rachmadi Usman 2001 Aspek-Aspek Hukum Perbankan di Indonesia Jakarta : PT Gramedia Pustama Utama p. 61.

${ }^{7}$ Hasanudin Rahman 2008 Jaminan Kebendaan Dalam Perjanjian Kredit Perbankan Bandung : Bumi Aksara p. 23

${ }^{8}$ Eddy Aman 2006 Putra Fungsi Jaminan dalam Kredit Perbankan Suatu Tinjauan Yuridis Jakarta : Raja Grafindo Persada p. 2

${ }^{9}$ Adrian Sutedi 2010 Hukum Jaminan Dalam Pelaksanaan Kredit Perbankan Bandung : Citra Aditya Bakti p. 30

${ }^{10}$ Subekti 2008 Suatu Tinjauan Tentang Sistem Hukum Jaminan Nasional Bandung : Binacipta p.27
} 
mentioned that the agreement may be accompanied by interest that has been previously agreed between the parties, so that the credit agreement can be entered into loan agreements with flowers herald.

In a bank credit agreement using Mortgage institution as collateral for a loan, banks as creditors holding only Encumbrance certificate that has been registered and issued by the land office where the object is located Encumbrance. While the loan recipient as the debtor retains or object occupying the Mortgage. In the certificate of ownership of the object Encumbrance by the land office had written the words that the ownership rights have been installed Mortgage as loan guarantees from the owner of the object Encumbrance to banks that provide credit. $^{11}$

As a rule, it is the confiscation was legal action taken at the level of the investigation, after passing the stage of investigation can no longer seizure on behalf of the investigators. ${ }^{12}$ The question is whether it can be done against the confiscation of all the objects regardless of the status of the object, or, objects how the nature and circumstances that can be done or confiscation placed on it. Therefore, seizure of objects that had nothing to do with the events that are being processed criminal law contrary to the applicable law, and declared invalid. This would be detrimental to the owner of the object, and he can lay claim to the court and filed a pretrial tuntan compensation.

J. Satrio argue, as the prosecutor has the right to confiscate all the executor can be proved it is the result of a crime. Throughout the foreclosure action only, not be a problem if the prosecutor confiscated (which had been confiscated as collateral civil cases). Article 39 of the Criminal Procedure Code is quite clearly stated criteria for objects that can be seized, namely: 1 . Object bill suspect or defendant allegedly obtained all or part of a criminal act or in part the result of a criminal act, 2 . Things that have been used directly committed the crime or to prepare a criminal offense. 3 . Things that used to obstruct the investigation of criminal offenses, 4. Objects specially made or intended to commit a crime. 5. Other objects that have a direct connection with the crime. ${ }^{13}$

\section{Research Methods}

In this research, legal research used juridical empirical approach. ${ }^{14}$ legal research is based on field research or primary data research to understand the symptoms of law which includes the communities associated with the general principles of law, rule of law, legislation, ${ }^{15}$ relating to collateral mortgages auctioned without an auction process execution request to the Chairman of the Court.

\footnotetext{
${ }^{11}$ Rusdy Murhainis 2009 Kredit Perbankan dan Lembaga Jaminan Hak Tanggungan Bandung : Bina Cipta p. 16

${ }^{12}$ Rusli Muhammad 2007 Hukum Acara Pidana Kontemporer Bandung : Citra Aditya Bakti p. 45.

${ }^{13}$ M. Karjadi dan R. Soesilo 2012 Kitab Undang-Undang Hukum Acara Pidana Dengan Penjelasannya Resmi dan Komentar Bogor: Politeia p. 46.

${ }^{14}$ Zainuddin Ali 2010 Metode Penelitian Hukum Jakarta: Sinar Grafika p 19

${ }^{15}$ Soerjono Soekanto and Sri Mamudji 2001 Penelitian Hukum Normatif suatu Tinjauan Singkat Jakarta: Radja Grafindo Persada p 11
} 
In this study the specifications of the research is a descriptive analysis, the research is intended for humans, state / other symptoms. ${ }^{16}$ Descriptive means to describe the symptoms of law, describing the systematic factual and accurate information about collateral mortgages auctioned without an auction process execution request to the Chairman of the Court, while analytical means to provide an assessment of the results of such depictions without intending to provide general conclusions.

\section{Results And Discussion}

\subsection{Forms Criminal Law Protection Against Giving Is Not Debtor Encumbrance}

Inlinguistic, said protection in the UK to discuss so-called protection. The term of protection according to $\mathrm{KBBI}$ can be equated with the term of protection, which means the process or act of arrest, while according to Black's Law Dictionary, protection is the act of protecting. ${ }^{17}$

Legal protection is to give shelter to human rights are harmed others and the protection given to the public so that they can enjoy all the rights conferred by law. ${ }^{18}$

Definition of legal protection for Indonesian people related in Dutch literature reads "rechtsbescherming van de Burgers tegen de overhead" and the literature of the English language is "Legal protection of the individual in relation to acts of administrative authorities".

Satjipto Raharjo defines the legal protection is to give shelter to human rights are harmed others and the protection given to the public with the aim that they can enjoy all the rights conferred by law. ${ }^{19}$

In general, the protection means protect something from things that are dangerous, something that could only be the interest and objects or goods. In addition it also implies the aegis of the protection given by a person against a weaker man. Thus, the protection of the law can be interpreted by all the government's efforts to ensure legal certainty to provide protection to its citizens so that your rights as a citizen is not violated, and those who violate them will be penalized according to regulations. ${ }^{20}$

To secure the implementation of the credit agreement made by the creditor against the debtor then be made binding agreement Mortgage guarantee where the debtor has the obligation to submit the immovable object in the form of land and buildings that have bersertipikat to be bound by the guarantee of mortgage. Object rights to land and buildings that have been tied to the collateral Mortgage still in the name of the debtor ownership, and can not be owned by creditors along debtor to perform its obligations in the payment of its debts to creditors. On the contrary, if the debtor defaults then the creditor by UUHT No. 4 of 1996 given the authority to execute on the security object Encumbrance in terms of take-back receivables unpaid by the debtor. ${ }^{21}$

\footnotetext{
${ }^{16}$ Bambang Sunggono 1997 Metodologi Penelitian Hukum Jakarta: Rajawali Press p 36

${ }^{17}$ Bryan A. Garner 2009 Black's Law Dictionary ninth edition St. paul: West p. 1343

${ }^{18}$ M Soerjono Soekanto 2006 Pengantar Penelitian Hukum Jakarta : UI-Perss p.133

${ }^{19}$ Satjipto Raharjo 2006 Ilmu Hukum Bandung: PT. Citra Aditya Bakti p. 54

${ }^{20}$ Pemegang Paten Perlu Perlindungan Hukum" Republika May 92018

${ }^{21}$ Rusdy Murhainis 2009 Kredit Perbankan dan Lembaga Jaminan Hak Tanggungan Bandung: Bina Cipta p. 16
} 
The principle of fairness in the implementation of the loan agreement with collateral Mortgage is also reflected in the provisions of Article 7 UUHT No. 4 of 1996 reads, "Encumbrance stay abreast of the object in the hands of anyone the object is" the provisions of Article 7 UUHT No. 4 In 1996, the fair gives legal protection to creditors Encumbrance certificate holder well-meaning in implementing agreements with the guarantee of mortgage credit. If the object of collateral debtors Mortgage divert it into the hands of a third party, then the security object Encumbrance remain the authority for the creditor and the creditor is entitled to execute the security object Mortgage object in the hands of anyone Mortgage collateral is located. ${ }^{22}$

\subsection{Effects Of Collateral Mortgage The Auction Process Execution Without Auctioned to the Chairman of the Court}

Credit according to Article 1 point 11 of Act No. 10 of 1998, is the provision of cash or the equivalent, based on agreements between bank lending and other parties who require the borrower to repay the debt after a certain period with the amount of interest.

Lending conducted by the bank as a financial institution, it should have to be able to provide legal protection for providers and recipients as well as those related credit protection through a strong guarantee rights institutions and to provide legal certainty for all parties concerned. ${ }^{23}$

Giving assurance of the debtor to the creditor must be accompanied by a security agreement that is set first in the credit agreement's status as a principal agreement underlying all forms thereafter agreements including collateral agreements. An agreement in principal, it should be mentioned in one of the clauses of the debtor promises to provide some assurance to the lender. Collateral agreement can not stand alone, but always following the principle agreement. If the principal agreement expires, the guarantee agreement also ended. The nature of such a treaty called accessoir.

Material guarantee is collateral in the form of an absolute right over a body, which has characteristics: has a direct relationship on a particular object of the debtor, can be defended against anyone, always follow the object (droit de suite) and can be transferred or transferred to another party. While the individual guarantee is a guarantee that pose a direct link to a particular individual, can only be defended against a particular debtor, against assets of the debtor in general. ${ }^{24}$

Objects guarantees can be divided into two guarantees movable and Security object is not moving, a special guarantee of immovable pertaining to land the most desirable lender is land that can be proved ownership by showing the certificate because it is not easily transferable, the price tends to increase, and have proof of entitlement. According Liliawati, Law of the Republic of Indonesia Number 4 of 1996 regulating

\footnotetext{
${ }^{22}$ Sri Soedewi Mascjchoen Sofwan 2000 Hukum Jaminan di Indonesia Pokok-Pokok Hukum Jaminan dan Jaminan Perorangan Yogyakarta: Liberty p. 67.

${ }^{23}$ Rudi Tri Santoso 2007 Prinsip Kehati-hatian Dalam Kredit Perbankan Yogyakarta: Liberty p. 33

${ }^{24}$ Sri Soedawi Masjchoen Sofwan 2003 Hukum Jaminan di Indonesia Pokok-pokok Hukum Jaminan dan Jaminan Perorangan Cetakan ke-3 Yogyakarta: Liberty Offset p. 46-47
} 
security rights over the land and objects related to the birth land to meet the needs of the community. ${ }^{25}$

Mariam Darus Badrulzaman, argues that the bank credit agreement is a preliminary agreement (vooroverenkomst) from the delivery of the money. ${ }^{26}$ Preliminary agreement is the result of a consensus between the giver and the recipient of the relationship between the two (creditors and debtors). The credit agreement is an agreement in principal (the principal) who is real. As a principal agreement, the credit agreement is equipped with a security agreement as his assessor. There and expiry of the guarantee depends on the principal agreement. The real meaning is that the credit agreement is determined by the delivery of money by banks to borrowers. ${ }^{27}$

The term "guarantee" is a translation of the word zekerheid or cautie, namely the ability of borrowers to meet or pay off perutangannya to creditors, which is done by holding certain objects that have economic value as a dependent on a loan or debt received by the debtor to the creditor.

Basically, collateral submitted to the lender is a guarantee of material and immaterial. Collateral material is a guarantee that the form of rights of material, good things not moving, such as land and / or home or moving objects such as vehicles, inventory (stock) of goods in warehouses and so on, or guarantee immaterial or collateral non materialism for example individual or personal guarantees gurantee.

Objects guarantees can be divided into two guarantees movable and Security object is not moving, a special guarantee of immovable pertaining to land the most desirable lender is land that can be proved ownership by showing the certificate because it is not easily transferable, the price tends to increase, and have proof of entitlement.

According to Act No. 5 of 1960 On Provisions Agrarian (hereinafter referred to as BAL), that the status of land ownership is evidenced by the certificate that the land is to have legal certainty that is strong, while the land has not bersertipikat does not have legal certainty, the ownership, location, extent and limits.

Security is the need to minimize the risk of creditors if the debtor is not able to solve all liability with respect to loans that have been disbursed. With the collateral if the debtor is unable to pay the debtor can impose payments on loans that have been given. $^{28}$

The position of the general guarantee under Article 1131 of the Civil Code which provides that all rights material debtor either moving or not moving, either already exist or will exist in the future be dependent on any perikatannya. The provisions of Article 1131 of the Civil Code is one of the basic provisions in the law guarantees, which regulates the position of the parties owe property (borrower) on the engagement debts. Inside the bank credit agreement of land as collateral.

In principle the provision of Encumbrance in lending to financial institutions, both banks and non-bank aims to protect the lender in order repayment of loans, if the debtor defaults but in reality the lender is very difficult to obtain repayment of the

\footnotetext{
${ }^{25}$ Eugema Liliawati Mulyono 2003 Tinjauan Yuridis Undang-undang Nomor 4 Tahun 1996 tentang Hak Tanggungan Dalam Kaitannya Dengan Pemberian Kredit Oleh Perbankan Jakarta: Harvarindo p 1

${ }^{26}$ Mariam Darul Badrulzaman 2001 Perjanjian Kredit Bank Bandung: PT. Citra Aditya Bakti p. 28

${ }^{27}$ Hermansyah 2007 Hukum Perbankan Nasional Indonesia Jakarta: Kencana p. 71.

${ }^{28}$ Badriyah Harun 2010 Penyelesaian Sengketa Kredit Bermasalah Yogyakarta: Pustaka Yustisia p. 67
} 
receivable if the debtor is concerned involved in a corruption and have sanctioned as mentioned in Article 18 of Law on Corruption Eradication. Problems of law arises when a debtor in a criminal case has been dropped corruption court decisions that have permanent legal force (inkracht van gewijsde) and the debtor are located in the debtor's insolvency or default automatically going bad debts. ${ }^{29}$

\section{Closing}

\subsection{Conclusion}

Mortgages carried on the request for the certificate holders of mortgage creditors first and the only one in a bank credit agreement as debtors in default in carrying out its debt payment obligations are valid and have binding force because is based on Articles 6, 14 and 20 UUHT No. 4 of 1996, which if the debtor defaults then the creditor is authorized to execute security object tanggunggan rights granted debtors and putting it through the auction to take repayment of its receivables. The execution carried out by its own power by a creditor under Article 14 UUHT No. 41996 where encumbrance certificate containing entittle "By Justice Based Almighty Deity" It has the same legal force court decisions that have permanent legal force. Implementation of the security object of mortgage sales through auction by the holder of the certificate of mortgage creditors first and the only one that has a preferential rights (precedence) of other creditor, based on Article 20 UUHT No. 41996.

Legal protection against the winner of the auction were bertiikad good on a lawsuit filed by the debtor giver Encumbrance is the winner of the auction must be protected their rights by law in terms of ownership of the object auction of objects collateral Mortgage that has been bought legally from auction agency conducting the auction accordance with applicable law.

\section{Suggestion}

- To avoid lest there be an execution Mortgage and to minimize the execution Encumbrance the creditor's worth a closer and more careful and selective in giving credit to the debtor by selecting debtors example, the characters, the economic capacity, capacity, condition, and etc.

- The extension of credit by the creditor to the debtor should guarantee a higher value than the loan value. It is intended, in case the auction execution, the object of collateral sufficient to charge penalties, interest, and the cost of the auction itself. Given the cost of the auction execution requires no small cost.

\section{Bibliography}

[1] Adrian Sutedi 2010 Hukum Jaminan Dalam Pelaksanaan Kredit Perbankan Bandung: Citra Aditya Bakti

\footnotetext{
${ }^{29}$ Ratna Sumarjanti 2007 Eksekusi Jaminan Hak Tanggungan Suatu Tinjauan Yuridis Jakarta: Aksara Baru p. 46
} 
[2] Badriyah Harun 2010 Penyelesaian Sengketa Kredit Bermasalah Yogyakarta: Pustaka Yustisia

[3] Bambang Sunggono 1997 Metodologi Penelitian Hukum Jakarta: Rajawali Press

[4] Eddy Aman Putra 2006 Fungsi Jaminan dalam Kredit Perbankan Suatu Tinjauan Yuridis Jakarta: Raja Grafindo Persada

[5] Eugema Liliawati Mulyono 2003 Tinjauan Yuridis Undang-undang Nomor 4 Tahun 1996 tentang Hak Tanggungan Dalam Kaitannya Dengan Pemberian Kredit Oleh Perbankan Jakarta: Harvarindo

[6] Hasanudin Rahman 2008Jaminan Kebendaan Dalam Perjanjian Kredit Perbankan Bandung: Bumi Aksara

[7] Hermansyah 2007 Hukum Perbankan Nasional Indonesia Jakarta: Kencana

[8] M. Karjadi dan R. Soesilo 2012 Kitab Undang-Undang Hukum Acara Pidana Dengan Penjelasannya Resmi dan Komentar Bogor: Politeia

[9] Mariam Darul Badrulzaman 2001 Perjanjian Kredit Bank Bandung: PT. Citra Aditya Bakti

[10] Rachmadi Usman 2001 Aspek-Aspek Hukum Perbankan di Indonesia Jakarta: PT Gramedia Pustama Utama

[11] Rusdy Murhainis 2009 Kredit Perbankan dan Lembaga Jaminan Hak Tanggungan Bandung: Bina Cipta

[12] Rusli Muhammad 2007 Hukum Acara Pidana Kontemporer Bandung: Citra Aditya Bakti

[13] Salim HS 2004 Perkembangan Hukum Jaminan di Indonesia Jakarta: PT. Radja Grafindo Persada

[14] Soerjono Soekanto dan Sri Mamudji 2001 Penelitian Hukum Normatif suatu Tinjauan Singkat Jakarta: Radja Grafindo Persada

[15] Sri Soedawi Masjchoen Sofwan 2003Hukum Jaminan di Indonesia Pokok-pokok Hukum Jaminan dan Jaminan Perorangan Yogyakarta: Liberty Offset

[16] Subekti 2008 Suatu Tinjauan Tentang Sistem Hukum Jaminan Nasional Bandung: Binacipta

[17] Zainuddin Ali 2010 Metode Penelitian Hukum Jakarta: Sinar Grafika 